\title{
Fiscal Decentralization and Economic Growth in Thailand: A Cross-Region Analysis
}

\author{
Phouthakannha Nantharath $^{1}$, Sirisak Laochankham ${ }^{2}$, Peerasit Kamnuasilpa ${ }^{2}$ \& Eungoo Kang ${ }^{3}$ \\ ${ }^{1}$ Faculty-Fiscal Management, College of Local Administration, Khon Kaen University, Thailand \\ ${ }^{2}$ Faculty-Local Governance, College of Local Administration, Khon Kaen University, Thailand \\ ${ }^{3}$ Saint Mary’s University of Minnesota, Minneapolis Minnesota, USA \\ Correspondence: Eungoo Kang, Post-Doctoral Researher, Saint Mary’s University of Minnesota, 9200 Queensland \\ Ln N. Maple Grove, Minnesota 55311, USA. E-mail: exkang14@smumn.edu
}

Received: August 28, 2019

doi:10.5430/ijfr.v11n1p147
Accepted: October 20, 2019

Online Published: October 24, 2019

\begin{abstract}
Prior to the 1997 decentralization, over $90 \%$ of national revenue in Thailand were held at the central government and less than $10 \%$ of public expenditure were allocated to local governments across country. Lack of adequate revenue and access to sufficient expenditure budget has caused disparity and ineffectiveness of public services and economic development at the local level. This study examines the effects of the fiscal decentralization on the economic growth in Thailand from 2004 to 2017. The research methodology uses a cross panel data analysis across five provincial regions and considers revenue decentralization, expenditure decentralization, transfer dependency, and vertical fiscal imbalance as influential factors of growth. By applying Panel Fully Modified Least Squares (FMOLS) and Panel Dynamic Least Squares (DOLS) regression approaches, the study finds empirical evidence of positive effects of revenue decentralization, transfer dependency, and vertical fiscal imbalance on regional economic growth across five regions. However, this study also finds that expenditure decentralization has a negative impact on regional economic growth, but level of significance is weak. These findings suggest that the rapid increase in metropolis government expenditure budget following the years of political transition in 2006 and 2014 has caused stagnation in public investment at local level across country, thereby resulted in a lagged behind industrial output and gross provincial product. Lack of budget expenditures also weakens demand and stagnates growth in manufacturing, construction, and real estate activities, thereby rendering fiscal imbalances and development gaps in Thai economy.
\end{abstract}

Keywords: decentralization, fiscal decentralization, development economics, economic growth, local government, Thailand

JEL Classifications: DO11, O23, O40, E62

\section{Introduction}

In recent year, the topic of decentralization has received great attention in the fields of public policy and economic development. In the developing world, countries have started to adapt to the idea of decentralizing governance in moving toward a more open, inclusive, and democratic system. One common goal of adopting this concept is to improve the quality of public service, increase efficiency in delivering welfare system, promote local economic growth, and maintaining macroeconomic stability in the long run (UNDP, 2005:2).

Decentralization in Thailand took place after the promulgation of the 1997 Constitution and the Determining Plans and Process of Decentralization Act 1999 (UNDP, 2009). The introducing of the national decentralization aimed at increasing autonomy and democracy at the local level through the transferring of resource and responsibilities from central government to local units. Although over the past three decades, the decentralization process has created many positive improvements nationwide, it faced challenges in many aspects of changes. This includes changes in: (1) organizational structures of local government bodies; (2) devolution of functions to local administrations; (3) local revenues and fiscal decentralization; (4) reforming the local personnel management system; (5) public participation; and, (6) changing approaches to monitoring local administration (UNDP, 1999).

Over the past three decades, there has been a considerable number of studies assessed the effectiveness of the decentralization in Thailand, but the findings remain ambiguous and mostly concentrated in the focus of intuition and 
case studies. From a fiscal management stand point, one can examine the relationship between the fiscal decentralization and regional economic growth based on an assumption that decentralization would allow autonomous power in fiscal management for local government in generating revenue, access to greater source of capital allocation, and being able to take control of the use of its own source of funding. Economically, this would render effects on economic efficiency, competition $\&$ innovation, and macroeconomic stability in the long run.

Theoretically, fiscal decentralization comes in many forms and is strategically implemented differently in different countries across the world. According to the World Bank (2019), the common forms of fiscal decentralization include: (1) self-financing or cost recovery through user charges, (2) co-financing or co-production arrangements through which the users participate in providing services and infrastructure through monetary or labor contributions; (3) expansion of local revenues through property or sales taxes, or indirect charges; (4) intergovernmental transfers that shift general revenues from taxes collected by the central government to local governments for general or specific uses; and (5) authorization of municipal borrowing and the mobilization of either national or local government resources through loan guarantees.

In Thailand, a major form of fiscal decentralization has been implemented through the process of intergovernmental transfers. Prior to the 1997 decentralization, over 90 percent of national revenue were held at the central government and less than 10 percent of public expenditure were allocated to local governments across country. Consequently, the lack of adequate revenue and access to sufficient capital has caused disparity and ineffectiveness of public services and economic development at the local level. To capture some empirical evidences of the effects of fiscal decentralization on growth in Thailand after 1997, this study examined the effects of the four primary key factors of fiscal decentralization on promoting the regional growth. These factors include: (1) revenue decentralization, (2) expenditure decentralization, (3) transfer dependency, and (4) vertical fiscal imbalance.

\section{Literature Review}

\subsection{Overview of Decentralization Around the World}

The popularity of decentralization has been evident since early 1980s (Conyers, 1983). However, decentralization or decentralizing governance has been beleaguered by questions surrounding its definition, whether the term is a theory, a concept, or just a restructuring framework in the governance system. At first, decentralization in developing countries was implemented for the economic purpose-largely focus on liberalizing marker and growth, later, the idea has been adopted for the political purpose-reforming public sector and devolving the functions of central government. Major policymakers have agreed that decentralization is a situation in which authority and responsibility for public functions are transferred from the central government to local governments, civil societies and other non-government organizations (Rondinell, Nellis, \& Cheema, 1999; UNDP, 2005:3). In practice, decentralization varies greatly in both forms and degrees worldwide. In the early days, decentralization was centered on the structural issues in federalism and constitutional design of revenue and expenditure (Ramesh, 2013). Later, the process started to gain momentum in democratization, public policy, and welfare delivering system. Three common types of decentralization include: (1) political decentralization, (2) administrative decentralization, and (3) fiscal decentralization.

In Europe decentralization was initially driven by the demand of democratic control and autonomy at local government due to the failure of the centralized states (Coulson, 1995). In Latin American countries, decentralization arose from the democratization processes that began in 1980s along with the state reforms aiming to increase state legitimacy and democratic governance through broader citizen participation, fiscal balance, and structured local government in order to implement social policies and deliver effective services (Finot, 2005).

Similarly, African countries started to implement the decentralizing system since mid-1980s. As a region with most diverse groups of population, African countries saw the process of decentralization to reduce poverty and management of violence conflict through the process of democratization and a more efficient economic resource allocation (Crawford \& Hartmann, 2008).

In Asia, trend of decentralization began as early as 1980s and spread across the region by 2000s (Malesky, Nguyen, \& Tran, 2012). However, effects and stages of decentralization vary across the regions and was largely evidenced in the form of expenditure reallocation at the subnational level. In country like China, India, Japan, and South Korea, both subnational expenditure and revenue increased substantially by 2000s (Brosio, 2014). While countries such as Indonesia, India, and Pakistan have been progressively decentralized over the past two decades, other countries like Cambodia, the Philippines, Lao PDR, and Vietnam are still at the initial stage. According to the Brosio \& Asian Development Bank (2014), share of state/provincial and local municipalities on total expenditure in Indonesia, India, and Pakistan were $40 \%, 33 \%$, and $28 \%$, respectively. In contrast, in the Philippines and Cambodia, the shares on expenditure of subnational government were at $11 \%$ and $19 \%$, respectively. 


\subsection{Local Government and Fiscal Decentralization in Thailand}

The public administration of Thailand composes of three key components, namely central administration, regional administration, and local administration. Prior to the promulgation of the 1997 Constitution, in Thailand, the central government was the sole authority that determines the political process, allocates budget, and sets outline for national expenditure. The old system allowed the central government to appoint provincial governors to supervise local administration. Local administrations, on the other hands, was considered as delegated agent in carrying out local affairs and had limited administrative capacity, fiscal autonomy, and responsibilities toward local people (Varanyuwatana \& Laovakul, 2010). The new Constitution marked a new era of the country's public sector reforms. It mandated the initiation of the decentralization and devolution processes of the resources and responsibilities from the central authorities to local governments. This mandate was promoted in the form of the Decentralization Act of 1999 which provided the framework to devolve 245 functions (6 major programs) from central government over a 10-year period and to increase the local government expenditure to at least 35 percent of national net revenue by the end of 2006 (Economic Research and training Center, 2009).

According to the Decentralization Act of 1999, the decentralization process emphasized on three areas including political, administrative, and fiscal decentralization. Subsequently, there were 7857 units total of local government and classified into five categories. These include: (1) Provincial Administrative Organization (PAO: 75 units), which serve as the upper unit of local government within province; (2) Municipality (1,156 units); (3) Sub-district (Tambon) Administrative Organization (TAO: 6,624 units); (4) Bangkok Metropolitan Administration (BMA); and (5) Pattaya City. (See figure 1).

Fiscal decentralization was considered a core component of the national decentralization. It played significant role in determining the progress and success of the entire process through the transferring of adequate revenue and funding to local governments. For local governments to carry out the decentralized functions effectively, they need to be financially self-reliant, i.e. being able to self-financed through local revenue collection and having autonomy in intergovernmental transfers. In Thailand, local government units receive two types of intergovernmental transfers based on the general and specific purposes. However, the amount of funding available each year is solely dependent of changes in the central government policy. In addition, the criteria of grant allocation at the central level is not very systematic (Economic Research and Training Center, 2009). The ultimate goal of intergovernmental transfers is to increase the revenue capacity and to promote spending on functions in public services and welfare delivering system.

Since 2001, two years after the Decentralization Act was put in effect, the local revenue share in Thailand has substantially increased over years. For instance, the local revenue share increased significantly from $11.5 \%$ in 2001 to $20.7 \%$ in 2002 and reached all time high of $25.2 \%$ in 2007 (Economic Research and Training Center, 2009). The benefits of this progress have not been only evident in the improvement of overall local public services nationwide, but also in the local economic development across regions as will be discussed in the follow up sections.

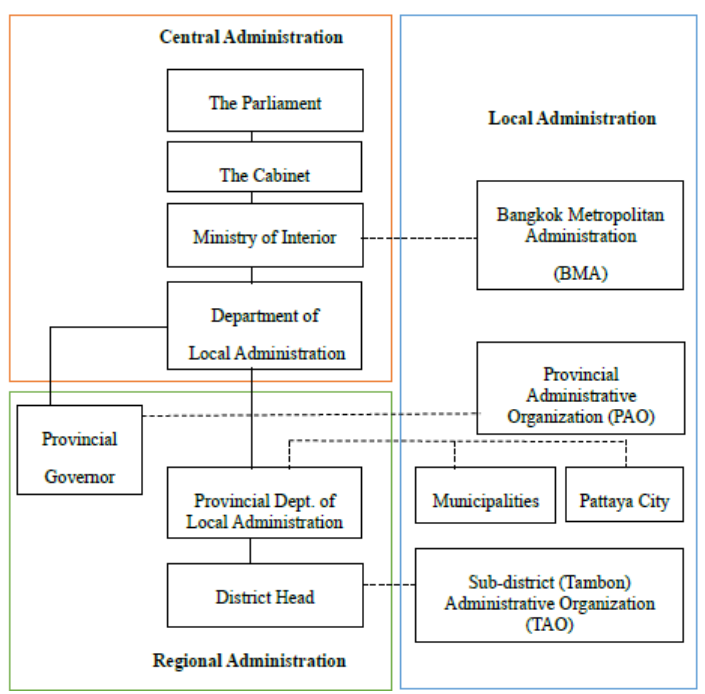

Figure 1. Administrative structure of The Thai Government

Source: The Secretariat of the Cabinet 


\subsection{Fiscal Decentralization and Economic Growth}

Although the theoretical studies of decentralization have been around since 1970s, the empirical evidence of the relationship between fiscal decentralization and economic growth has only received a numerous attention in 1990s. More specifically, there is a considerable number of studies being conducted in the cases of developing and transition economies such as Russia, Eastern Europe, China, and Southeast Asia. By definition, fiscal decentralization is the process of the devolution of fiscal powers from central government to subnational subordinates. The significant effect of fiscal decentralization across developing ountries has been the redistribution of budget allocation. In practice, this subsequently increases the budget flow and public investment across country, thereby stimulating the process of growth and economic development nationwide.

Theoretically, fiscal decentralization influences economic growth in several ways. From a practical standpoint, it increases economic efficiency in public expenditure (providing public goods and services), encourages competition and innovation in fiscal management, and promotes macroeconomic stability in the long run (Musgrave, 1959; Oates, 1972). Tiebout (1956) and Oates (1972) argue that fiscal decentralization provides greater economic efficiency in resource allocation at subnational level. The argument being that local government can provide tailor-made solutions to public needs across localities, while central governments tend to emphasize on standardized public service across country. The first reason that spurs up information advantage at local level is the mobility of individual across jurisdictions which enhance the efficiency and create interregional spillover effects. In other words, at local level, individuals can migrate around and cross jurisdictions to find places where public service \& investment are best matched with their preferences. Ganaie, Bhat, Kamaiah, \&Khan (2018) explain that any attempt of revenue maximization at local level could result in a migration of citizens and firms to other jurisdictions with lower tax rate. Second, at local level, citizens have better and closer relation with local policymakers, hence, have higher power to influence an informed decision and policy relating to their needs and benefits. Subsequently, it is possible that the local governments have better knowledge \& understanding of basic need and public goods at local level than the central government (Rodriguez-Pose and Ezcurra, 2010; Lessmann and Markwardt, 2012; Baskaran, Feld, \& Schnellenbach, 2016).

Brennan \& Buchanan (1980) argue that fiscal decentralization increases the horizontal and vertical fiscal competition of local government and limits the size of the public sector and its incentives. This argument links the citizens' preferences to policy innovation. Because public needs at local level always change over short period of time, local governments are forced to be responsive to public aspiration (Hayek, 1948). Strumpf (2002) describes that decentralization leads to policy innovation when citizens' choices could serve as a laboratory for social and economic experiments. In such case, local governments are encouraged to engage with central government and compete among each other to attract more expenditure budget. The competition among local governments motivates citizen's engagement and encourage government's honesty, efficiency, and responsiveness, thereby resulting in innovative resource allocation (Weingast, 1995).

Although there is ambiguous literature of relationship between decentralization and economic performance around the world, prominent studies have agreed that decentralization affects economic growth directly and indirectly through the allocative efficiency and improved public services (Saito, 2008). The effects of fiscal decentralization on macroeconomic stability can be explained by a macroeconomic production function, where output is driven by physical capital, labor input, and total-factor productivity. A neoclassical growth model such as Solow's (1956) explains the total-factor productivity in a form of technological progress which is the primary factor in sustaining the permanent long-run economic growth. In practice, productivity and technological progress are influenced by many factors including institutional quality, policy design, as well as fiscal frameworks (Blöchliger \& Akgun, 2018). For instance, public investment in education and healthcare would increase the quality of human capital, which in turn contributing to earning and growth.

\section{Analytical Framework}

\subsection{Data}

The panel data includes five regions of the Kingdom of Thailand (Bangkok Metropolis, Central, North, Northeast, and South). Altogether, the five regions consist of 73 provinces, excluded four provinces from the East region. Variables include gross provincial product (GPP) as dependent variable, gross fixed capital (GFC), number of populations (Pop) as control variables, and four indicators of fiscal decentralization which include: revenue decentralization (A1), expenditure decentralization (A2), transfer dependency (A3), and vertical fiscal imbalance (A4). All variables were constructed on the basis of revenue and expenditure data of the regional and central government. The selection of the fiscal indicators was based on Fiscal Decentralization Methodological approach of 
the International Monetary Fund (IMF, 2018), the studies from Ganaie et al. (2018); Escolano et al. (2012); Eyraud and Lusinyan (2011); Dziobek, Gutierrez Mangas and Kufa (2011); and Akai and Sakata (2002). In addition, we used the gross fixed capital of manufacturing, construction, and real estate activities as the proxy for capital stock of each region.

Data are collected from office of the National Economic and Social Development Council (NESDB), National Statistical Office (NSO), the Bank of Thailand (BOT), Budget Bureau (BB), Fiscal Policy Office (FPO), Ministry of Finance (MOF), and Parliamentary Budget Office (PBO). Time span of data cover a period from 2004 to 2017. Overall, there is a total of 70 observations. Except fiscal decentralization indicators, gross provincial product, population, and gross fixed capital variables are converted into the natural logarithm units.

Table 1. Description of variables

\begin{tabular}{lll}
\hline & Variables & Description of Variables \\
\hline $\mathbf{1}$ & LnGsdp & Gross Provincial Product (at constant prices) \\
\hline $\mathbf{2}$ & LnGFC & Gross fixed capital \\
\hline $\mathbf{3}$ & LnPop & Population \\
\hline Fiscal Decentralization Indicators \\
\hline $\mathbf{4}$ & $\mathbf{A 1}$ & Revenue decentralization (ratio of own revenue to general government revenue) \\
\hline $\mathbf{5}$ & $\mathbf{A 2}$ & Expenditure decentralization (ratio of own expenditure to general government expenditure) \\
\hline $\mathbf{6}$ & $\mathbf{A 3}$ & Transfer dependency (ratio of net transfers to own revenue) \\
\hline $\mathbf{7}$ & $\mathbf{A 4}$ & Vertical fiscal imbalance (1- ratio own revenue to own expenditure) \\
\hline
\end{tabular}

Source: International Monetary Fund (IMF, 2018); Ganaie et.al. (2018)

\subsection{Research Model}

The research model was constructed using the production function and growth accounting approach, suggested by Solow (1956). The data analysis adopted econometrics of panel data analysis using Panel Fully Modified Least Squares (FMOLS) and Panel Dynamic Least Squares (DOLS) regression approaches. Importance steps of panel data analysis include panel unit root test and panel cointegration test. Both unit root and cointegration tests were required to verify the validity of regression and long-run relationship between variables.

We derived our model from the following production function:

$$
Y_{i t}=A_{i t} L_{i t}^{\alpha} K_{i t}^{\beta}
$$

Where $\mathrm{Y}$ is the output, $\mathrm{L}$ denotes the labor stock, $\mathrm{K}$ denotes capital stock, and A represents the level of technology. In Solow's Model, A is being described as the Solow's residual or the influence of technological progress of growth. $0<\alpha<1,0<\beta<1, \alpha+\beta=1$.

Rewriting equation (1) in a linear form by taking a natural logarithm on both sides gives:

$$
\ln \left(Y_{i t}\right)=\ln \left(A_{i t}\right)+\alpha \ln \left(L_{i t}\right)+\beta \ln \left(K_{i t}\right)
$$

Taking a total derivative gives:

$$
y_{i t}=\phi_{i t} a_{i t}+\gamma_{i t} l_{i t}+\eta_{i t} k_{i t}+\varepsilon_{i t}
$$

Replacing output (Y) with gross provincial product (GPP), labor stock (L) with number of populations (Pop) and capital stock (K) with gross fixed capital (GFC), we rewrote (3) as:

$$
G p p_{i t}=\phi_{i t} a_{i t}+\gamma_{i t} P_{o p} p_{i t}+\eta_{i t} G f c_{i t}+\varepsilon_{i t}
$$

Barro's (1991) endogenous growth model assumes that the government partakes in private-sector output and facilitates free public services. Thereby, technological progress in the Solow's growth model could also be 
influenced by the fiscal decentralization in the forms of government budget expenditure and revenue (Davoodi and Zou, 1998; Iimi, 2005; Kim, 2013), we rewrote (4) as follow:

$$
G p p_{i t}=\phi_{i t} f d_{i t}+\gamma_{i t} P_{o p} p_{i t}+\eta_{i t} G f c_{i t}+\varepsilon_{i t}
$$

Where $f d$ is a function of government budget expenditure and revenue and can be expressed as:

$f d=f($ gov.expenditure, gov. revenue);

$i=1, \ldots .5$ and $t=2004, \ldots . .2017$

\section{Empirical Analysis}

\subsection{Panel Unite Root Test}

Panel unit root test was conducted to verify the stationarity of the variables under the assumption that variables are stationary if their values have no unit roots. In this case, a unit root test is important as it helps to ensure that we were not dealing with a spurious regression. In this study, we used Levin-Lui-Chu test and Augmented Dickey-Fuller test to confirm the unit root test results.

Table 3 shows that all variables are non-stationary at level, but stationary at first difference, I(1). This result mandated us to perform the panel cointegration test to verify the long-run relationship between dependent and independent variables.

Table 2. Panel unit root test (t-statistics, p-value)

\begin{tabular}{lllll}
\hline \multirow{2}{*}{$\begin{array}{l}\text { Fiscal } \\
\text { Indicators }\end{array}$} & Decentralization & \multicolumn{2}{l}{ Levin-Lin-Chu test } & \multicolumn{2}{l}{ Augmented Dickey-Fuller test } \\
\cline { 2 - 5 } & Level & First Difference & Level & First Difference \\
\hline LnGPP & -1.69323 & -2.94506 & 8.88863 & 26.2264 \\
& $(0.0452)^{*}$ & $(0.0016)^{*}$ & $(0.5427)$ & $(0.0034)^{*}$ \\
\hline LnPop & -2.73715 & -1.92141 & 35.9595 & 23.4063 \\
& $(0.0031)^{*}$ & $(0.0273)^{*}$ & $(0.0001)^{*}$ & $(0.0093)^{*}$ \\
\hline LnGFC & -3.26890 & -4.51270 & 11.1218 & 36.7912 \\
& $(0.0005)^{*}$ & $(0.0000)^{*}$ & $(0.3481)$ & $(0.0001)^{*}$ \\
\hline A1 & -0.46901 & -8.11235 & 8.68769 & 65.1515 \\
& $(0.3195)$ & $(0.0000)^{*}$ & $(0.5620)$ & $(0.0000)^{*}$ \\
\hline A2 & 1.48104 & -8.76590 & 10.5969 & 63.1032 \\
& $(0.9307)$ & $(0.0000)^{*}$ & $(0.3898)$ & $(0.0000)^{*}$ \\
\hline A3 & -0.32961 & -7.63418 & 20.1683 & 54.7905 \\
& $(0.3708)$ & $(0.0000)^{*}$ & $(0.0277)^{*}$ & $(0.0000)^{*}$ \\
\hline A4 & -1.48325 & -9.31329 & 16.5814 & 71.3302 \\
& $(0.0690)$ & $(0.0000)^{*}$ & $(0.0842)$ & $(0.0000)^{*}$ \\
\hline
\end{tabular}

*Indicating p-value rejected the Null Hypothesis

\subsection{Panel Cointegration Test}

Since variables are stationary at first difference, I(1), we needed to check the existence of cointegration. Cointegration test suggests that there exists long-run relationship between variables, if two series have constant co-variance over time. In this study, we used two cointegration test methods, viz. Pedroni (1999; 2004) and Kao (1999). Both methods are based on Engle-Granger (1987) two-step (residual-based) cointegration tests. The test results presented in Table 3a and Table $3 \mathrm{~b}$ confirm that variables are cointegrated. 
Table 3a. Pedroni cointegration test

\begin{tabular}{llll}
\hline Dimension & Test Statistics & Intercept & Intercept and Trend \\
\hline Within-dimension & Panel v-Statistic & -1.208484 & 2.915104 \\
& & $(0.8866)$ & $(0.0018)^{* * *}$ \\
\cline { 2 - 4 } & Panel rho-Statistic & 3.315723 & 2.707325 \\
& & $(0.9995)$ & $(0.9966)$ \\
\cline { 2 - 4 } & Panel PP-Statistic & 2.183767 & -2.314657 \\
& & $(0.9855)$ & $(0.0103)^{* * *}$ \\
\cline { 2 - 4 } & Panel ADF-Statistic & 0.158721 & -1.243055 \\
& & $(0.5631)$ & $(0.1069)$ \\
\hline Between-dimension & Group rho-Statistic & 3.377566 & 3.493132 \\
& & $(0.9996)$ & $(0.9998)$ \\
\cline { 2 - 4 } & Group PP-Statistic & -6.066806 & -7.936381 \\
& & $(0.0000)^{* * *}$ & $(0.0000)^{* * *}$ \\
\cline { 2 - 4 } & Group ADF-Statistic & -2.945530 & -3.619551 \\
& & $(0.0016)^{* * *}$ & $(0.0001)^{* * *}$
\end{tabular}

*** Indicating p-value rejected the Null Hypothesis

Table 3b. Kao residual cointegration test

\begin{tabular}{lll}
\hline & t-Statistic & Prob. \\
\hline ADF & -4.102322 & $0.0000 * * *$ \\
\hline Residual Variance & 0.001406 & \\
\hline HAC variance & 0.000697 & \\
\hline
\end{tabular}

*** Indicating p-value rejected the Null Hypothesis

\subsection{Panel Ordinary Least Squares (OLS)}

The existence of cointegration gave us the validity to model the long-run relationship of variables. In this study, we used the panel Fully Modified OLS (FMOLS) model and Panel Dynamic Least Squares (DOLS) methods to estimate the coefficient of long-run relationship of the variables and level significance on influencing the growth.

The regression results of FMOLS show that the coefficient of expenditure decentralization (A2) is negative and not significant at five percent level $(\mathrm{p}$-value $=0.085)$, while the effects of revenue decentralization $(\mathrm{A} 1)$, transfer dependency (A3), and vertical fiscal imbalance (A4) are positive and significant at five percent level (p-value = $0.0516,0.0008$, and 0.0175 , respectively).

The regression of DOLS, on the other hand, shows a similar result. While the coefficient of expenditure decentralization (A2) is negative and not significant at five percent level ( $\mathrm{p}$-value $=0.1485$ ), the influence on growth of variables, A1, A3, and A4 are positive and significant at five percent level, p-value $=0.0398,0.0170$, and 0.0120, respectively.

Table 4. FMOLS and DOLS regressions

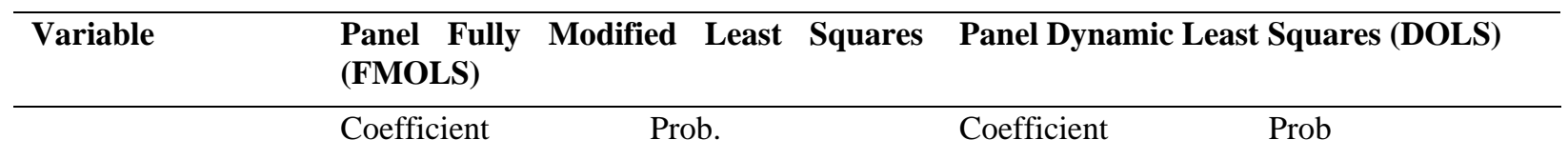




\begin{tabular}{lllll}
\hline LNPOP & 1.310438 & 0.3444 & 0.904920 & 0.6947 \\
\hline LNGFC & 0.988633 & 0.0000 & 0.965333 & 0.0000 \\
\hline A1 & 6.774620 & $0.0505^{* *}$ & 5.807833 & $0.0398^{* * *}$ \\
\hline A2 & -2.158324 & 0.1516 & -1.816229 & 0.1485 \\
\hline A3 & 0.191623 & $0.0008^{* * *}$ & 0.176360 & $0.0170^{* * *}$ \\
\hline A4 & -0.159820 & $0.0175^{* * *}$ & -0.149391 & $0.0120^{* * *}$ \\
\hline
\end{tabular}

*** Indicating coefficient is significant at p-value $<0.05$

\section{Conclusion}

The regressions of FMOLS and DOLS share consensus in results. This study found that, over the period 2004 to 2017, there is empirical evidence that fiscal decentralization has positively contributed to the progress of economic growth in Thailand. More specifically, revenue decentralization, transfer dependency, and vertical fiscal imbalance have positively affected economic growth across five regions of the country. However, this study also finds that expenditure decentralization has a negative impact on regional economic growth, but level of significance is weak. These findings align with the empirical evidence from the studies of fiscal decentralization and economic growth in OECD economies by Asatryan, Feld, \& Geys (2015) and Blochliger and Akgun (2018), both of whom described that decentralization of tax revenues tends to have a stronger impact than spending decentralization and such evidence is more likely to occur in a smaller government. While intergovernmental transfers appeared to be associated with slower growth, both studies found that balanced decentralization is conducive to growth.

Although there is a lack of empirical evidence from the effect of expenditure decentralization on growth, its negative impact at p-value $<0.15$ merits further investigation. Since 2006, Thai economy has been suffering from the political instability which rendered significant impact on relationship between central and local governments, more specifically on the budget redistribution to subnational governments across country. For instance, the 2006 coup d'etat gave the opportunity for interim government to maintain local revenue at $25 \%$ and dismissed the intergovernmental transfer (Varanyuwatana \& Laovakul, 2010). Such evidence can also be numerically observed in the national budget expenditure allocation from 2004 to 2017. Over this period, the annual budget allocated to Bangkok Metropolis government increased significantly following the year of military coups. For instance, Bangkok Metropolis budget expenditure increased from 126,039 million baht in 2014 to 566,045 million baht in 2015 (or increased by $349.10 \%$ ), and to $1,724,845$ million baht in 2016 (or increased by $204.72 \%$ ). The rapid increase in metropolis government budget subsequently reduced the budget allocated to the local governments. As a result, there was a stagnation in public investment at local level across the country, thereby caused a lagged behind industrial output and gross provincial product. Lack of budget expenditures resulted in weakening demand and stagnation in growth of manufacturing, construction, and real estate activities, thereby causing fiscal imbalances and development gaps in Thai economy.

Although significant evidences have been found, this study faced limitations in obtaining a more complete set of fiscal decentralization indicator data such as tax revenue decentralization, VAT-share of general government, social contribution, education- share of general government, health- share of general government, etc. as suggested by the IMF's fiscal decentralization data set. Future studies of similar topics that incorporate the aforementioned indicators may find more evidences and different explanations of the relationship between fiscal decentralization and regional economic growth in Thailand.

\section{References}

Akai, N., \& Sakata, M. (2002). Fiscal decentralization contributes to economic growth: Evidence from state-level cross-section data for the United States. Journal of Urban Economics, 52(1), 93-108. https://doi.org/10.1016/S0094-1190(02)00018-9

Asatryan, Z., Feld, L. P., \& Geys, B. (2015). Partial fiscal decentralization and sub-national government fiscal discipline: empirical evidence from OECD countries. Public Choice, 163(3-4), 307-320. https://doi.org/10.1007/s11127-015-0250-2

Barro, R. J. (1991). Economic growth in a cross section of countries. The Quarterly Journal of Economics, 106(2), 407-443. https://doi.org/10.2307/2937943 
Baskaran, T., Feld, L. P., \& Schnellenbach, J. (2016). Fiscal Federalism, Decentralization, and Economic Growth: A Meta-Analysis. Economic Inquiry, 54(3), 1445-1463. https://doi.org/10.1111/ecin.12331

Blöchliger, H., \& Akgun, O. (2018). Fiscal decentralization and economic growth. In J. Kim, \& S. Dougherty (Eds.), Fiscal Decentralization and Inclusive Growth. OECD Publishing, Paris. https://doi.org/10.1787/9789264302488-4-en

Brennan, G., \& Buchanan, J. M. (1980). The power to tax: Analytic foundations of a fiscal constitution. Cambridge University Press.

Brosio, G. (2014). Decentralization and Public Service Delivery in Asia. Asian Development Bank Economics Working Paper Series No.389. https://doi.org/10.2139/ssrn.2479233

Campbell, J. Y., \& Shiller, R. J. (1987). Cointegration and tests of present value models. Journal of Political Economy, 95(5), 1062-1088. https://doi.org/10.1086/261502

Conyers, D. (1983). Decentralization: The Latest Fashion in Development Administration?. Public Administration and Development, 3, 97-109. https://doi.org/10.1002/pad.4230030202

Coulson, A. (1995). Local government in Eastern Europe: establishing democracy at the grassroots. Edward Elgar: Aldershot.

Crawford, G., \& Hartmann, C. (2008). Introduction: Decentralization as a Pathway out of Poverty and Conflict?. In G. Crawford, \& C. Hartmann (Eds.), Decentralization in Africa: A Pathway out of Poverty and Conflict? (pp. 7-32). Amsterdam: Amsterdam University Press. https://doi.org/10.5117/9789053569344

Davoodi, H., \& Zou, H. F. (1998). Fiscal decentralization and economic growth: A cross-country study. Journal of Urban Economics, 43(2), 244-257. https://doi.org/10.1006/juec.1997.2042

Dziobek, C., Gutierrez Mangas, C. A., \& Kufa, P. (2011). Measuring fiscal decentralization-exploring the IMF's databases. IMF Working Paper No.11/126 (pp. 1-30). Washington, DC: IMF. https://doi.org/10.5089/9781455263431.001

Economic Research and Training Center. (2019). Decentralization and the budget for social services at tambon administrative level: Thailand. Bangkok: Economic Research and Training Center, Faculty of Economics, Thammasat University.

Escolano, J., Eyraud, L., Moreno Badia, M., Sarnes, J., \& Tuladhar, A. (2012). Fiscal performance, institutional design and decentralization in European Union countries. IMF Working Paper No. 45. Washington, DC: IMF.

Eyraud, L., \& Lusinyan, L. (2011). Decentralizing spending more than revenue: Does it hurt fiscal performance?. IMF Working Paper No. 11/226. Washington, DC: IMF. https://doi.org/10.5089/9781463904944.001

Finot, I. (2005). Decentralization, territorial transfers and local development. CEPAL Review, (86), 27-44. https://doi.org/10.18356/3e4cd457-en

Ganaie, A. A., Bhat, S. A., Kamaiah, B., \& Khan, N. A. (2018). Fiscal Decentralization and Economic Growth: Evidence from Indian States. South Asian Journal of Macroeconomics and Public Finance, 7(1), 83-108. https://doi.org/10.1177/2277978718760071

Hayek, F. A. (1948) Individualism and Economic Order. London and Chicago: George Routledge and University of Chicago Press.

Iimi, A. (2005). Decentralization and economic growth revisited: An empirical note. Journal of Urban Economics, 57(3), 449-461. https://doi.org/10.1016/j.jue.2004.12.007

Kao, C., \& Chiang, M. H. (2001). On the estimation and inference of a cointegrated regression in panel data. In Nonstationary panels, panel cointegration, and dynamic panels (pp. 179-222). Emerald Group Publishing Limited. https://doi.org/10.1016/S0731-9053(00)15007-8

Kim, H. (2013). Fiscal decentralization and economic growth in Korea. Korea Institute of Public Finance.

Lessmann, C., \& Markwardt, G. (2012). Aid, growth and devolution. World Development, 40(9), 1723-1749. https://doi.org/10.1016/j.worlddev.2012.04.023

Malesky, E. J., Nguyen, C. V., \& Tran, A. (2012, October 23). The economic impact of recentralization: A quasi-experiment on abolishing elected councils in Vietnam. Mimeo.

Oates, W. (1972). Fiscal decentralization. New York, NY: Harcort Brace Javanovich. 
Pedroni, P. (1999). Critical values for cointegration tests in heterogeneous panels with multiple regressors. Oxford Bulletin of Economics and Statistics, 61(S1), 653-670. https://doi.org/10.1111/1468-0084.61.s1.14

Pedroni, P. (2004). Panel cointegration: asymptotic and finite sample properties of pooled time series tests with an application to the PPP hypothesis. Econometric Theory, 20(3), 597-625. https://doi.org/10.1017/S0266466604203073

Ramesh, M. (2013). Decentralization in Asia: Survey. Policy and Society, 32, 1-5. https://doi.org/10.1016/j.polsoc.2013.02.004

Rodríguez-Pose, A., \& Ezcurra, R. (2010). Is fiscal decentralization harmful for economic growth? Evidence from the OECD countries. Journal of Economic Geography, 11(4), 619-643. https://doi.org/10.1093/jeg/lbq025

Rondinelli, D. A., Nellis, J. R., \& Cheema, G. S. (1983). Decentralization in developing countries. World Bank Staff Working Paper No. 581.

Saito, F. (2008). Decentralization and local governance: introduction and overview. In Foundations for local governance (pp. 1-24). Physica-Verlag HD. https://doi.org/10.1007/978-3-7908-2006-5_1

Solow, R. M. (1956). A contribution to the theory of economic growth. The Quarterly Journal of Economics, 70(1), 65-94. https://doi.org/10.2307/1884513

Strumpf, K. S. (2002). Does government decentralization increase policy innovation?. Journal of Public Economic Theory, 4(2), 207-241. https://doi.org/10.1111/1467-9779.00096

Tiebout, C. M. (1956). A pure theory of local expenditures. The Journal of Political Economy, 64(5), 416-424. https://doi.org/10.1086/257839

UNDP. (1999). Decentralization: A Sampling of Definitions. Working paper prepared in connection with the Joint UNDP-Government of Germany evaluation of the UNDP role in decentralization and local governance. Decentralization: A Sampling of Definitions. Retrieved from http://web.undp.org/evaluation/documents/decentralization_working_report.PDF

UNDP. (2005). Fiscal Decentralization and Poverty Reduction. Retrieved from http://www.undp.org/content/dam/aplaws/publication/en/publications/poverty-reduction/poverty-website/fiscaldecentralization-and-poverty-reduction/FiscalDecentralizationandPovertyReduction.pdf

Varanyuwatana, S., \& Laovakul, D. (2010, March). Progress of fiscal decentralization in Thailand. Conference: A Comparative Perspective between Thailand and Indonesia. Bangkok: Thammasat University.

Weingast, B. R. (1995). The economic role of political institutions: Market-preserving federalism and economic development. Journal of Law, Economics, \& Organization, 1-31.

World Bank. (2019). Fiscal Decentralization. Retrieved August 5, 2019, from http://www1.worldbank.org/publicsector/decentralization/fiscal.htm 